\title{
Corporate Social Responsibility Disclosures, Traditionalism and Politics: A Story from a Traditional Setting
}

\author{
Shahzad Uddin ${ }^{1} \cdot$ Javed Siddiqui $^{2} \cdot$ Muhammad Azizul Islam $^{3}$
}

Received: 21 April 2015/Accepted: 15 May 2016/Published online: 26 May 2016

(c) The Author(s) 2016. This article is published with open access at Springerlink.com

\begin{abstract}
This paper demonstrates the political perspective of corporate social responsibility (CSR) disclosures and, drawing on Weber's notion of traditionalism, seeks to explain what motivates companies to make such disclosures in a traditional setting. Annual reports of 23 banking companies in Bangladesh are analysed over the period 2009-2012. This is supplemented by a review of documentary evidence on the political and social activities of corporations and reports published in national and international newspapers. We found that, in the banking companies over the period of study, apparently neutral, corporate, philanthropic activities disclosed and promoted in CSR reports are inextricably linked to powerful leaders' personal projects and the ruling party's agendas. We have demonstrated elements of traditional societies, including personal loyalty and the public display of loyalty, the master-servant relationship, and obedience to personal rather than formal authority, provide an understanding of why banks (with or without explicit political linkages with the ruling party) have employed politically charged CSR disclosure strategies. The paper contributes to disclosure studies where political motivations of corporate disclosure rarely discussed. The paper extends the debate on political CSR by demonstrating that the role of family and familial values at the organisational and national levels may be much more important when it comes to CSR disclosure and activities.
\end{abstract}

Javed Siddiqui

javed.siddiqui@mbs.ac.uk

1 University of Essex, Colchester, UK

2 Alliance Manchester Business School, University of Manchester, Manchester, UK

3 Queensland University of Technology, Brisbane, Australia
Keywords Corporate social responsibility disclosures . Traditionalism · Politics · Families · Traditional settings · Bangladesh

\section{Introduction}

This paper is concerned with the political perspective of corporate social responsibility (CSR) disclosures. Research on CSR disclosures, in general, has received attention from academics, policymakers, practitioners and wider stakeholder groups (Mathews 1997; Parker 2005; Owen 2008; Deegan 2014). It has been argued that, while CSR may be a strategy for redistributing income from corporations to the general public, paradoxically CSR disclosures may potentially provide a setting for political interests and patronage (Cooper and Owen 2007). However, the political perspective of CSR is under-theorised (Whelan 2012) and has rarely appeared in disclosure studies (Gu et al. 2013). This paper aims to fill this gap in drawing on the disclosures of corporations.

The prevalence of political interests and patronage in corporations is well noted in the literature (Muthuri and Gilbert 2011; Chapple and Moon 2007; Prechel and Morris 2010; Walker and Rea 2014; Lux et al. 2011). The political ties of corporations and their influence on corporate conduct take different shapes and forms, depending on the institutional and political settings of the countries in which they operate (Matten and Moon 2008; Dieleman and Boddewyn 2012). Previous studies have argued that countries with under-developed democratic institutions, family-led politics and poverty, which are more likely to be prevalent in traditional settings (Tsamenyi and Uddin 2008), create the necessary conditions for strong political ties between political elites and businesses (Berglöf and 
Claessens 2006; Dieleman and Boddewyn 2012). ${ }^{1}$ For instance, Dieleman and Boddewyn (2012) found that business groups in Indonesia are both highly dependent on governments to secure key resources, and face a unique set of risks associated with political ties. Similarly, Yadav (2011) has argued that the close relationship between political parties and business groups enables political elites to strongly influence corporate conduct in emerging economies.

Previous studies have demonstrated that the social, economic, cultural and political context of corporations is an important factor leading to differences in CSR across nations (Matten and Moon 2008; Chapple and Moon 2007). Matten and Moon (2008) found that CSR differences in Europe and the USA are due largely to underlying institutional and contextual features embedded in businesses. Focusing on the human rights practices of ten Chinese state-owned enterprises, Whelan and Muthuri (forthcoming) found that pressures at national and intraorganisational levels are critical to conforming with international guidelines on human rights. Given that corporate conduct is often influenced by state politics and political elites, corporations are likely to employ CSR disclosures to seek out and manage political ties (Gu et al. 2013; Muthuri and Gilbert 2011; Chapple and Moon 2007). ${ }^{2}$ Against this background, this paper examines whether corporations in traditional settings exploit CSR disclosures to seek out and manage political ties and, if so, how. It also explores how the political nature of CSR disclosures might be explained.

The Bangladeshi situation is particularly useful for developing our understanding of political perspectives of CSR disclosures. Firstly, the nature of politics and democracy in Bangladesh provides a unique opportunity to shed light on the use of CSR disclosures and its connection with political regimes (Uddin and Hopper 2001). The country has a fragile democratic system, and is subject to frequent violent confrontations between two family-led political parties (Uddin and Choudhury 2008). Secondly, a striking feature of businesses in Bangladesh is the existence of political patronage. It is claimed that political identity plays a crucial role in the process of granting licences to businesses (Uddin and Hopper 2003; Kochanek

\footnotetext{
${ }^{1}$ In this paper, the term "traditional setting" is used interchangeably with "emerging economy" or "poorer country". Weber (1978) articulates traditional settings as those in which traditional values supersede a rational and legalistic model of society and economy. Democracy, politics and state machineries are overpowered by family values and connections, leading to under-developed markets and institutions. Personal loyalty, obedience, obligations to personal chief and being subject to a superior are necessary elements to maintain a traditional society and economic activities.

${ }^{2}$ Political ties may involve relationships with the ruling party, polities, elites and even the head of the government.
}

2000). Thirdly, conditions such as under-developed democratic institutions, poverty, family ownership, lack of institutional investors, and weak capital markets in Bangladesh are well noted in the literature (Uddin and Choudhury 2008). ${ }^{3}$

Empirically, this paper focuses on banking companies in Bangladesh to investigate patterns of CSR disclosure and the influence of politics. Banks are considered to be the engine room and key to economic development and poverty alleviation in poorer countries (Beck et al. 2011). Both state and private banks must operate within the strict guidelines of various regulatory bodies, including the central bank. Their CSR activities attract special attention from policymakers and academics, perhaps in view of the role that financial institutions are supposed to play in economic development. Since 1990, there has been phenomenal growth in banks in emerging economies, which has attracted considerable public attention in recent years (World Bank 2005). Nevertheless, the study of CSR disclosures by financial institutions, especially in emerging economies, remains neglected (Khan et al. 2011).

Theoretically, this study draws on Weber's notion of "traditionalism" to develop a broader understanding of the political perspectives of CSR disclosures. We examine whether elements of traditionalism provide deeper insights into political aspects of the CSR disclosure practices of banking companies in Bangladesh. Studies such as those by Uddin and Chowdhury (2008) and Dyball and Valcarcel (1999) draw heavily on Weber's thought, and this paper contributes to the tradition of Weberian explanations of accounting practices. This is further explained and justified in later sections.

The paper begins with a brief review of previous studies of CSR disclosures and the role of politics, followed by a section on traditionalism. It then provides a brief historical and cultural background to the Bangladeshi banking sector, and a description of the research methods used in this study. The empirical findings are presented and discussed, and conclusions are drawn in the final section.

\section{CSR, Disclosures and Politics}

While early CSR disclosure studies focused on the general nature of social and environmental reporting issues (Hackston and Milne 1996; Mathews 1997), a growing body of research is focusing on specific CSR issues and associated disclosures. For instance, recent CSR disclosure

\footnotetext{
${ }^{3}$ Institutional shareholding is fragmented. Uddin and Choudhury (2008) found that only 5.81 per cent of shares are held by 88 institutions in the top 20 performing companies on the Dhaka Stock Exchange.
} 
studies have drawn attention to sustainability reporting (Byrch et al. 2015; Higgins et al. 2014; Tregidga et al. 2014; Milne and Gray 2013), climate change and accounting for bio-diversity (see special issues of $A c$ counting, Auditing \& Accountability Journal in 2013 and 2014, respectively), human rights accounting (see special issue of Accounting, Auditing \& Accountability Journal in 2016), and anti-corruption or anti-bribery disclosures (see Islam et al. 2016).

Previous studies on CSR disclosures have reported a number of drivers/motivations, including market, community and stakeholder influence (Dhaliwal et al. 2011; Deegan and Blomquist 2006; Cooper and Owen 2007). A significant number of studies has been devoted to understanding CSR disclosures in relation to legitimacy in wider society and stakeholders' interests (Guthrie and Parker 1989; Deegan 2002; Bebbington et al. 2008; Deegan 2014). Laine $(2009,2010)$ has demonstrated how companies have changed the rhetoric of environmental disclosures and sustainability-related concepts over the years in order to maintain a legitimate position in wider society. While longitudinal studies offer opportunities to research potential links between changing political ideologies and CSR disclosures, the politically motivated CSR disclosures of corporations remains under-researched within the accounting literature.

Within the business ethics and business and society literature, research has increasingly been conducted on political CSR, although this has concentrated mainly on the political duties and activities of corporations, and MNCs in particular (e.g. Crane et al. 2008; Hsieh 2009; Palazzo and Scherer 2006). Within this normative tradition, researchers find that Western MNCs play positive roles in societies (Scherer et al. 2006, 2009). It has been suggested that increased globalisation has resulted in a decline in the power of the state, thereby allowing MNCs to step into that role (Whelan 2012). Whelan (2012) offers a robust critique to this stream of research and calls for 'critical' research into the political CSR agenda. He critiques three aspects: wrongly equating globalisation with diminished capacities of the state; assuming that MNC motivations can, do or might oscillate between a rational profit-seeking and prosocial logic; and the existence of a political model of corporate governance facilitating MNCs' CSR activities (Whelan 2012, p. 710).

Although our study draws on national companies and their disclosure patterns to articulate the political aspects of disclosure, it does offer support for Whelan's critique of political CSR. We share wider views on political CSR which argue that different CSR contexts and challenges, such as poverty, labour standards, bases of governmental power and legitimacy, cultural traditions and historical factors, are likely to be crucial to corporations' CSR activities (Chapple and Moon 2007). We argue that the nature and capacities of the state or family-led state (in case of traditional societies) continue to exert a strong influence over corporate conduct, including CSR (Uddin and Choudhury 2008).

Early CSR studies of emerging economies were descriptive in nature and mainly exhibited a low level of CSR disclosure (Tsang 1998; Hegde et al. 1997; Jaggi and Zhao 1996). Later studies have focused on identifying the drivers of CSR in corporations (Momin and Parker 2013; Belal and Roberts 2010; Islam and Deegan 2008). International pressure from national and international media, foreign partners and donors has been found to be a significant driver of CSR disclosure in Bangladesh only in internationally linked companies (Siddiqui and Uddin 2016; Islam and Deegan 2008). Nevertheless, the political motivations of CSR disclosures do not seem to feature in the above studies, with the exception of $\mathrm{Gu}$ et al.'s (2013) work, which demonstrates that stronger political connections lead to greater adoption of CSR disclosures.

The political motivations of CSR disclosures need further examination and theorisation, given the critical role that politics play in shaping corporate conduct (Berglöf and Claessens 2006; Yadav 2011). This paper responds to Whelan's (2012) call to explain political CSR through a range of more sophisticated theories. We draw on Weber's concept of "traditionalism", embodying elements such as family, kinship, personal loyalty and master-servant relationships that influence the operating practices of corporations, including CSR. This will be further discussed in the next section.

\section{Weber's Notion of "Traditionalism" and CSR}

Weber emphasises the importance of social, economic, cultural and historical factors in shaping a particular form of society (such as traditionalist), and their implications for organisational accountability and transparency. For instance, he sees rational capitalism as having been only partially realised in the Western industrial revolutions of the eighteenth and nineteenth centuries. He also recognises traditional forms of capitalism that exist throughout the world even now and which were evident in Europe until the eighteenth century (Uddin and Choudhury 2008, p. 1029). Weber's (1923) work on Indian societies argues that the suppression of intra-community (Weber terms it 'Demiurgie') and promotion of inter-community division of labour under the patrimonial political domination have strengthened traditional societies and subverted the money economy and rational capitalism. The development of intra-community division of labour 
(Demiurgie $)^{4}$ in Europe gradually changes its form into the Demiurgie of a money economy. In India and other Asiatic societies, the development of Demiurgie was blocked at its first beginnings by the patrimonial states/ tribal lords. Instead inter-community division of labour was promoted within the political domain of a patrimonial state or a tribal lord. In India, it was later reinforced by the caste system (Otsuka 1966).

Traditional societies exhibit economic activities promoting the property and productive capacities of individual economic units geared primarily towards satisfying the needs and preferences of the master or family/clan (Dyball and Valcarcel 1999). This has been demonstrated in many societies, including Bangladesh (Uddin and Choudhury 2008). Personal loyalty, obedience, obligations to personal chief and being subject to a superior are necessary elements in maintaining a traditional society and economic activities. According to Weber (1947):

The person exercising authority is not a "superior", but a personal "chief". His administrative staff does not consist primarily of officials, but of personal retainers. Those subject to authority are not "members" of an association, but are either his traditional "comrades" or his "subjects". What determines the relations of the administrative staff to the chief is not the impersonal obligations of office, but personal loyalty to the chief. Obedience is not owed to enacted rules, but to the person who occupies a position of authority... who has been chosen for such a position (Weber 1947, p. 341).

Traditionalism is further clarified by Uddin and Choudhury (2008) and Dyball and Valcarcel (1999). Referring to Weber's work, the latter argue that:

The "master" is expected to do good turns, governed by an ethical common sense of equity or of utilitarian expediency. His exercise of power is bound only by resistance from his "subjects". It is impossible then for an "impartial" law or administrative rule to be intentionally created by legislation (p. 307).

Traditionalism seems to stand in the way of the ideal development of markets and makes rational capitalism difficult to develop. Weber's (1923) work advances these arguments, focusing on traditional communities in Indian villages (McLane 1993). The break-up of traditional social relations in early European societies was led by the intracommunity division of labour and the rise of occupational

\footnotetext{
$\overline{4}$ This refers to that state of social division of labour in which workers other than farming comprehended within the land occupancy relations of the traditional community. These workers include carpenters, blacksmith, potters, barbers, etc. They are found to serve the village community.
}

communities, which in turn led to a money economy and the development of capitalism in Western countries. In contrast, intra-community division of labour and occupational communities in Asian and African societies were thwarted by the caste system in India and by various geographical and economic conditions and tribal relations in other societies (McLane 1993; Hart 1982; Hopkins 1976).

Drawing on Weber's (1978) characterisation of rational and traditional societies, Dyball et al. (2006, p. 53) highlight further differences between the two, arguing, in Weberian terms, that the institutions of community, market and state are conjoined in traditional societies. Several key elements of traditionalism appear to constitute traditional societies, including personal loyalty and the public display of loyalty, the master-servant relationship, and obedience to personal rather than formal authority. We examine whether these elements enable us to explain the CSR practices of Bangladeshi banks. In adding to the theoretical lenses appropriated for disclosure (Deegan 2002, 2014) and political CSR studies (Whelan 2012), we would argue that Weber's work on traditionalism is pertinent to understanding political aspects of CSR disclosures in traditional societies such as Bangladesh. ${ }^{5}$ This is justified below.

Firstly, the development of an ideal form of capitalism in Bangladesh and other traditional societies has been thwarted by various historical and cultural mediations, including British and other colonial interventions, religious interventions and families (Weber 1923; Uddin and Hopper 2001). Elements of traditionalism such as family dominations are deeply rooted in traditional societies, as in Bangladesh, and extend to organisational settings (Uddin 2009; BEI 2004). Thus, elements of traditionalism such as personal loyalty or obedience to personal rather than formal authority will be useful notions to explain organisational practices including disclosure patterns in family-dominated businesses.

Secondly, the two family-led political parties have controlled state power since the independence of Bangladesh in 1971 (Mannan 2011). The confrontational politics pursued by these two leading political parties have led to the capture of state-run institutions while in power (Uddin and Choudhury 2008). The family-led state dominates both private and public corporations (BEI 2004). Weber's traditional societies exhibit a similar feature, so it would be useful to examine how the ruling party and its powerful leaders influence the CSR practices of corporations from the perspective of traditionalism. Interestingly, this notion of the power of the family-led state runs contrary to ideas expressed in much of the political CSR literature (critically

\footnotetext{
5 Institutional theories (Whelan and Muthuri forthcoming; Muthuri and Gilbert 2011) and resource dependency theory (Dieleman and Boddewyn 2012) have been appropriated in this stream of research.
} 
see Whelan 2012; Whelan and Muthuri forthcoming) that the diminished role of the state is replaced by MNCs and international agencies (e.g. international non-government organisations such as Amnesty International, inter-governmental organisations such as the UN) in promoting and enforcing CSR standards (e.g. Scherer and Palazzo 2011).

Thirdly, factors driving CSR disclosures in traditional societies may not be the same as in advanced societies. The use of legitimacy and stakeholder theories has benefited CSR studies, but a more thorough explanation of the use of disclosures is necessary, especially for emerging economies. Legitimacy to the state and wider stakeholders may be of significant value to corporate managers in Western countries (Deegan 2002). Appeasing wider stakeholders may also be significant for corporations in Western countries (Deegan and Blomquist 2006). However, it is questionable whether the idea of legitimacy to wider stakeholders, contrary to much of the political CSR literature, has any attraction for corporations in traditional settings, given that the nature and power of the state and state-like bodies are personified in familial politics.

Works by Uddin and Choudhury (2008) and Uddin (2009) demonstrate that managers of even stock marketlisted companies in Bangladesh seem to serve the interests of sponsoring directors (and their families), often at the expense of majority shareholders and other stakeholders. Hence, activities are directed towards the "master" rather than wider society, further strengthening the bond between "master" and "servant". The relationship between the ruling party and corporations is perhaps better captured in "master-servant" relationship providing deeper explanations of CSR disclosures practised by companies located in traditional settings.

Finally, previous studies have demonstrated the usefulness of Weber's works for accounting, especially in the areas of the development of accounting knowledge and professions, accounting controls and corporate governance (Chua and Poullaos 1998; Caramanis 2005; Dyball et al. 2006). Nevertheless, the CSR disclosure literature has not made use of Weber's work. We believe that Weber's notions of rationality and traditionalism have much to offer to disclosure studies. The use of "traditionalism" in the accounting literature is not new, but the use of this theoretical idea in the context of capitalistic firms located in traditional settings perhaps has more promise in explaining disclosure practices.

\section{Research Methods}

Our research attempts to discern political elements in reported CSR disclosure items. In a study such as this, the accurate identification of CSR disclosures of a political nature is crucial. We used thematic content analysis ${ }^{6}$ based on phrases to identify the nature of the CSR disclosures (Weber 1990). The method adopted in our study was inspired by previous studies (Campbell and Abdul Rahman 2010; Samkin et al. 2014). Samkin et al. (2014) used text units, ranging from a short sentence to individual paragraphs, to identify specific themes which were then classified into three broad categories. In our case, two of the authors identified political contributions and statements through a close reading of the annual reports, CSR reports and websites of the banking companies. To ensure the consistency and reliability of the process, disagreements were resolved through a close reading by the third author.

We have reviewed the company reports for the period 2009-2012 of all listed and non-listed local banks operating in Bangladesh (a total of 39 banks). Of the 39 local banks, 16 banks (two state-owned, nine private and five development banks) either did not produce any information on their CSR activities or produced insufficient information to warrant inclusion in our further investigations. Therefore, our final analysis is based on 23 banks over a period of 4 years (2009-2012, 92 firm-years). In 2008, the central bank (Bangladesh Bank) initiated a drive to mainstream CSR engagements in the banking sector. As part of this initiative, the Bangladesh Bank started to publish an annual review of the CSR expenditure of banks in Bangladesh, although this is only available for 2008-2011. Hence, we chose to analyse the CSR data of banks since 2009. However, due to the lack of availability of recent (post2012) CSR data, the analysis presented in this study is limited to a period of 4 years (2009-2012).

In addition to company reports and announcements, we spent considerable time in collecting additional documentary evidence, such as newspaper reports relating to political announcements, and banking disclosures appearing in the national and international media during the sample period. Newspaper search engines provided information regarding key management personnel in the banks to enable political connections to be traced (presented in Table 1). Another important source of information on banking disclosures was institutional reports, such as central bank annual disclosure review documents, government circulars on fiscal incentives, and the International Finance Corporation's (IFC's) framework or Global Reporting Initiative (GRI) published during the study period. Information from the above sources was crucial in understanding the expectations of CSR disclosures from key stakeholders such as the central bank and international partners.

Skippari's (2005) framework was employed as a guideline to identify the politically connected disclosure

\footnotetext{
${ }^{6}$ Weber (1990) defines themes as a cluster of words with different meanings or connotations that, when taken together, form an issue.
} 
Table 1 Political links of banks

\begin{tabular}{lll}
\hline Bank & $\begin{array}{l}\text { Political } \\
\text { affiliation }\end{array}$ & Explicit political link
\end{tabular}

Panel A: political links of existing banks (Source: profiles of directors disclosed in annual reports of banking companies)

Private banks

\begin{tabular}{|c|c|c|}
\hline AB Bank & No & \\
\hline Al Arafah Bank & No & \\
\hline Bank Asia & Yes & Former minister's family members in BoD \\
\hline BCBL & No & \\
\hline BRAC Bank & No & \\
\hline City Bank & Yes & Former MP is the founding Chairman of the BoD. Two sons are on the BoD \\
\hline Dhaka Bank & Yes & Founding chairman is a former MP \\
\hline Dutch Bangla Bank & No & \\
\hline EBL & No & \\
\hline Exim Bank & No & \\
\hline First Security & No & \\
\hline ICB Islamic Bank & No & \\
\hline IFIC Bank & Yes & Chairman of the BoD is a current MP \\
\hline Islami Bank & Yes & Several members in BoD are linked with a political party \\
\hline Jamuna Bank & Yes & Key member of the $\mathrm{BoD}$ is a current MP \\
\hline Mercantile Bank & Yes & Chairman of the BoD is a current MP \\
\hline Mutual Trust Bank & No & \\
\hline National Bank & Yes & Founding chairman of the $\mathrm{BoD}$ is a former MP \\
\hline NCC Bank & Yes & $\begin{array}{l}\text { Chairman of the BoD is an elected leader of the chamber of commerce and industry and associated } \\
\text { with the ruling party }\end{array}$ \\
\hline One Bank & No & \\
\hline Premier Bank & Yes & Chairman of the BoD is a current MP \\
\hline Prime Bank & Yes & Chairman of the BoD is linked with ex Prime Minister \\
\hline Pubali Bank & Yes & Chairman of the BoD is a current MP \\
\hline Shahjalal Bank & No & \\
\hline Social Islami bank & No & \\
\hline Southeast Bank & No & \\
\hline $\begin{array}{l}\text { Standard Bank } \\
\text { Limited }\end{array}$ & Yes & Chairman is an advisor to a major political party \\
\hline Trust Bank & No & \\
\hline UCBL & Yes & Chairman of the BoD is a current MP \\
\hline Uttara Bank & No & \\
\hline \multicolumn{3}{|l|}{ State Banks } \\
\hline Sonali Bank & Yes & $\begin{array}{l}\text { Chairman is a pro-government academic (contested university senate elections from the pro- } \\
\text { government panel) }\end{array}$ \\
\hline Agrani Bank & Yes & $\begin{array}{l}\text { Chairman is a pro-government academic (was a former president of the university teachers' } \\
\text { association, contested university senate elections from the pro-government panel) }\end{array}$ \\
\hline Rupali Bank & Yes & Chairman is a political appointee (members of the political party) \\
\hline Janata Bank & Yes & $\begin{array}{l}\text { Chairman is a pro-government academic (contested university senate elections from the pro- } \\
\text { government panel) }\end{array}$ \\
\hline \multicolumn{3}{|l|}{ Development Banks } \\
\hline $\begin{array}{l}\text { Bangladesh Krishi } \\
\text { Bank }\end{array}$ & No & \\
\hline $\begin{array}{l}\text { Karnasangsthan } \\
\text { Bank }\end{array}$ & Yes & Chairman of the $\mathrm{BoD}$ is politically linked with the ruling regime \\
\hline
\end{tabular}


Table 1 continued

\begin{tabular}{|c|c|c|}
\hline Bank & $\begin{array}{l}\text { Political } \\
\text { affiliation }\end{array}$ & Explicit political link \\
\hline RAKUB & No & \\
\hline $\begin{array}{l}\text { Bangladesh } \\
\text { Development Bank }\end{array}$ & Yes & Chairman of the BoD is associated with the ruling party \\
\hline $\begin{array}{l}\text { BASIC Bank } \\
\text { Limited }\end{array}$ & Yes & Chairman of the BoD is a current MP \\
\hline \multicolumn{3}{|c|}{ Panel B: political links of six new banks in 2013 (Source: The Daily Star 2012) } \\
\hline Union Bank Limited & Yes & $\begin{array}{l}\text { Major shareholders include a former President of Bangladesh, who is currently in the ruling party } \\
\text { alliance }\end{array}$ \\
\hline $\begin{array}{l}\text { Modhumati Bank } \\
\text { Limited }\end{array}$ & Yes & Major shareholders include a current MP \\
\hline Meghna Bank Limited & Yes & Major shareholders include a current MP \\
\hline $\begin{array}{l}\text { The Farmers' Bank } \\
\text { Limited }\end{array}$ & Yes & Proposed chairman is a current MP \\
\hline South Bangla & Yes & Sponsor shareholder-a current MP \\
\hline Midland Bank Limited & Yes & $\begin{array}{l}\text { Key shareholder is a politically affiliated former bureaucrat, also the chairman of the BoD of the } \\
\text { Karnasangsthan Bank, a development bank }\end{array}$ \\
\hline
\end{tabular}

$B o D$ Board of directors

items. Skippari (2005) identifies five categories of corporate political activity: election funding and petitions, executive lobbying, advocacy, advertising and coalition building. These categories ${ }^{7}$ enabled us to group disclosure items. Given corporations are not allowed to provide election funding to political parties in Bangladesh, in our content analysis, we could only use the latter four categories of political activity. Our analysis identified 252 incidences of such politically connected disclosures during the sample period. These were then transferred to a coding spreadsheet. The coding process involved identifying specific themes which would fall into these four categories. Of the 252 incidents of corporate political activity, none fell into the "advocacy" category, and there was only one example of the "advertising" category. ${ }^{8}$ The rest fell into two categories: executive lobbying and coalition building. This initial grouping of politically connected disclosure items helped us to identify two most frequently recurring themes. They were "contributions supporting the ruling

\footnotetext{
7 Skippari's paper provides examples of political actions that fall under each of these categories. For example, 'petitions' involve sending formal communication to government as a response to increased government regulations; 'coalition building' includes actions taken to build a coalition with the government; 'advocacy advertising' involves attempts to indirectly support political views by influencing broader public opinion; 'executive lobbying' refers to actions taken by executives to personally contact political decision makers.

${ }^{8}$ In 2009, Southeast Bank ran an advertisement in national dailies congratulating the prime minister on receiving the "South-South" award.
}

party's agendas" (advertising and coalition building category") and "contributions to personal projects of leaders" (executive lobbying category ${ }^{10}$ ). Examples of CSR activities that fell into these two major recurring themes are as follows:

1. Contributions supporting the ruling party's agendas Disclosure items supporting the ruling party (Awami League) election manifestos and projects were grouped under this category. ${ }^{11}$ We found plenty of evidence of this type of CSR disclosure. Two items disclosed most frequently in annual reports were donations to the Liberation War Museum and donations to the Bangladesh Rifles (BDR) tragedy. Donations to the Liberation

\footnotetext{
9 According to Skippari (2005), 'coalition building' is a tactic to improve collective power. Skippari (2005) notes that coalitions between business executives and politicians can be of a temporary, issue-by-issue nature or a more permanent nature (for example, formulating a trade association that supports a particular political view). This is where the company executives and the politicians take collective actions to pursue a particular agenda.

${ }^{10}$ Executive lobbying refers to attempts made by corporate executives to 'personally' contact political decision makers (Skippari 2005). Skippari (2005) notes that the executive lobbying strategy can be more commonly observed in some countries (mainly traditional settings), in which 'personal connections between business executives and politicians' have been traditionally close (Katzenstein 1985; Murtha and Lenway 1994).

${ }^{11}$ We acknowledge that differentiating political parties' projects and politicians' personal projects is not straightforward in a family-led political context. Nevertheless, we have relied on current election manifestos and the ideological positions of the ruling party to identify contributions supporting the ruling party's agendas.
} 
War Museum had been mentioned in the election manifesto of the ruling party, while the BDR tragedy was used as a vehicle to repair differences between the army and the ruling party. Examples drawn from annual reports of contributions supporting the ruling party's agendas include "the bank made a donation of Tk 50 lacs (Tk 5 million) for the Mukitjoddha Jadughar [the Liberation War Museum] (IFIC Bank Annual Report 2010, p. 15); "Rupali Bank Limited sponsored National Media Ltd. to make and broadcast two rare exclusive documentaries named 'Nine Months to Freedom' (58 min colour) and 'Meeting a Milestone' (28 min colour) and footage of the War of Liberation and [the father of the nation] on different media in December, 2010. It helped reveal new evidence of our struggle for independence and the unparalleled leadership of [the father of the nation]" (Rupali Bank Annual Report 2010, p. 109).

2. Contributions to personal projects of leaders Items indicating close/personal relationships with leading political families were grouped under this category. Most CSR disclosure items were found to be associated with powerful leaders of the ruling party. These included items such as one-off payments to organisations named after members of the ruling party, and contributions to projects actively supported and sponsored by such members. Two of the most frequent disclosures broadly within this theme included donations to victims of Nimtoli (prime minister's personal call) and contributions to autism causes (prime minister's daughter's involvement). Instances of such reports include "Donation to Sheikh Jamal Club Limited [a club named after the current PM's brother-undisclosed amount]" (Jamuna Bank Annual Report 2011, p. 163) and "Pubali Bank has donated an amount of Tk 2.5 million to the Prime Minister's relief and welfare fund to help the Nimtoli tragedy victims" (Pubali Bank Annual Report 2010, p. 25).

The above categorisations are useful for identifying and classifying politically charged disclosures. These patterns of disclosure enable us to understand the influence of family-led state politics. Weber's notion of traditionalism provides further explanation of why personal loyalty is more important in driving disclosures than pressure from multilateral agencies (e.g. IFC, UN, Climate Change campaign).

Furthermore, Weber's methodologies inspired us to examine external layers (structural and historical conditions) which might shed light on organisational practices, in this case CSR. In order to understand the influence of traditionalism on CSR disclosure practices, we reviewed the political and social literature, as well as articles published in national and international newspapers, to gain an understanding of the historical and structural contexts in which these organisations were located. According to Weber, these are separate but interacting methodologies. The following sections discuss the historical and cultural conditions of Bangladeshi financial institutions and the CSR practices of banking companies.

\section{Traditionalism, Politics and Banking in Bangladesh}

Bangladesh (then called East Bengal), a part of India, was ruled by both Muslim and Hindu emperors for centuries. East Bengal and other parts of India were composed mainly of village communities led by local kings forming paternalistic states (Weber 1923). The mode of production was mainly farming. Intra-community labour division was not fully developed into money economy but promoted occupational labour communities to serve their localities controlled by the paternalistic states/tribal lords. This was further fixed by the cast systems in India. The arrival of the East India Company (1757) and the British India (1857) did not change the traditional power base arising from village communities but further reinforced the power structure, such as the power of zamindars or landlords (McLane 1993). The traditional local power base was conducive to producing raw materials for British industries whilst simultaneously maintaining traditional communities (McLane 1993). In 1945, Bangladesh became part of Pakistan and was known as East Pakistan. The new country began to industrialise by encouraging families, through various incentives, to make protected investments. The emergence of family entrepreneurs was unsurprising given the strength of families/clans in societies even in twentiethcentury West and East Pakistan (now Bangladesh). However, discriminatory economic development agendas by the ruling regime originated from West Pakistan promoted few West Pakistani families to own most of the industrial assets of Pakistan (Humphrey 1987). As a result, only a handful of West Pakistani families dominated the corporate sector of Bangladesh (then East Pakistan) during the 24 years of the Pakistan period. Soon or just before the independence of Bangladesh, most of these Pakistani families left Bangladesh partly because of fear of retaliation by Bangladeshis. This led to a vacuum, with an underdevelopment of local capital markets and a lack of private capital, when Bangladesh finally became independent in 1971 (Khan 1986).

After a brief period of "state capitalism" in Bangladesh (Uddin and Hopper 2001), the state, governed by familyled political parties (Uddin and Choudhury 2008) and dictated by global, political and economic conditions, 
began to sell public enterprises to individuals/families, giving rise to crony capitalism. Weber's (1923, 1978) works suggest similar outcomes: the structural conditions for rational capitalism struggle in the context of traditionalism, as in the strong presence of family and clan culture (Dyball et al. 2006; Dyball and Valcarcel 1999). Weber (1978) recognised the effects of familial or clan ownership on external accountability (Uddin 2009, p. 786). This has also been reported in previous studies. As Uddin and Hopper (2003, p. 768) report, "coupled to poor financial regulation and legal enforcement and weak capital markets, it was a breeding ground for crony capitalism associated with familial transacting, patronage, and irregular financial practices". Uddin and Choudhury (2008) argue that this poor form of governance and accountability is also linked with post-independence Bangladesh's family-led political parties.

Since independence, Bangladesh has been ruled predominantly by two major family-led political parties: the Sheikh Mujib family leads the Bangladesh Awami League, and the Zia family leads the Bangladesh Nationalist Party. The leaders of both parties inherited their positions in the political arena from deceased leaders. Unsurprisingly, resonating with traditionalism, neither political party is known for practising democratic norms. The parties appear to be controlled mainly by their kin and relatives (Mannan 2006; Sobhan and Ahmad 1980). The eldest sons of both leaders have been brought into politics and groomed to take over from their "mothers" (Mannan 2011). ${ }^{12}$ Heredity politics shape both local and national leadership and economy.

Political factionalism and the personification of state institutions are rife in Bangladesh. The increasing influence of tribunes (protectors/champions/heads of clan) and their family members puts pressure on the existing public institutions of state and civil society, resulting in disorganisation and deinstitutionalisation (Mannan 1992, p. 52). Previous studies have argued that, when these families come into power, they themselves erode the constitution and institutions at all levels (Hyden 1983; Mannan 1992, p. 52). The Institute of Governance Studies (2008) reports that, in a culture of political confrontation leading to patron-client relationships, the ruling party attempts to create loyalty and allegiance to state institutions, resulting in the widespread politicisation of such institutions, especially in their bureaucracy. Political division is so deeply rooted that even candidates contesting elections of a nonpolitical nature (for example, elections for professional bodies such as a university teachers' association, doctors'

\footnotetext{
12 Khaleda Zia leads the Bangladesh Nationalist Party, with her son, Tareq Rahman (Zia) standing in line; Sheikh Hasina (Wazed) leads the Awami League, with her son, Sajeeb Wazed Joy in line.
}

association, engineers' association, supreme court bar association, journalists' association, etc.) will need to have direct backing from one of the parties. Both parties have student factions in higher educational institutions and labour unions in all state-owned entities (Uddin and Hopper 2001).

The confrontational politics pursued by these two leading political parties have led to the creation of a culture that permits only wealthy people to be elected to public offices. While many politicians think the easiest way to earn money is through business, many businessmen believe seeking and maintaining political ties will help them expand their business (Zaman 2011). Active participation in politics by businessmen is quite common which has reflected in past parliamentary elections in Bangladesh. According to the declarations of candidates, 68 per cent of members of parliament elected in 2008 were businessmen (The Daily Star 2015). Mahmud et al. (2008) point out that a parliament dominated by businessmen contributed to the strong political ties between family-led political parties and businesses. As a result, political patronage has become almost a necessary condition for obtaining government permission to operate in banking, media and the emerging telecommunications sector.

Any change in the composition of state political leadership invariably leads to a reshuffling of every sector, including banking, in such a way that party loyalists receive maximum benefits (Khan 2003). Uddin and Choudhury (2008) argue that loyalty to families, rather than the application of professional judgment, skills and expertise, plays an important role in career advancement. Business opportunities depend not on commercial success but on exhibitions of public loyalty to the family in power. It would be unsurprising to see senior bank officials in Bangladesh employing CSR activities and disclosure as vehicles through which to demonstrate loyalty to the elected party/family. These issues will be examined more closely in connection with CSR disclosures in banking institutions.

An interesting, and perhaps unique feature of the banking sector in Bangladesh is the banks' explicit political affiliations. At present, there are 39 banks (excluding six newly approved banks and Grameen Bank $)^{13}$ operating in Bangladesh: four state-owned, 30 private, nine foreign and five specialist development banks.

Table 1 Panel A presents some explicit political links of local banks in Bangladesh. Twenty-one out of 39 local banks seem to have some form of connection with the ruling regime or other political parties through their

\footnotetext{
${ }^{13}$ Unlike other banks in Bangladesh, the Grameen Bank was promulgated by a special Grameen Bank Ordinance, 1983, and does not fall under the purview of the Banking Companies Act, 1991.
} 
chairman, sponsor director or influential board members being members of parliament, party members or vocal supporters of a political party. Table 1 Panel B illustrates that all six newly approved banks are connected with the ruling party, with sponsor directors/key shareholders being current parliament members or high-profile political leaders (Siddiqui 2010; The Daily Star 2012). The finance minister publicly admitted: "it is our political decision to issue licenses for new banks in the country despite reservations made by the Bangladesh Bank" (The Financial Express 2011). Banks without explicit political links do not necessarily make less politically charged disclosures, but the above table nonetheless highlights a unique feature of the banking establishment in Bangladesh. The next sections focus on CSR disclosures and their likely connections with politics.

\section{CSR Disclosures and Politics}

CSR disclosures are voluntary for listed and non-listed companies in Bangladesh, as in many other countries. Nevertheless, certain incentives have been put in place, especially for banking companies, through fiscal regulations and central bank directives. The central bank of Bangladesh (Bangladesh Bank) formed a partnership with the International Finance Corporation (IFC) soon after the Copenhagen climate change conference in 2009. Bangladesh has been identified as one of the most vulnerable countries to climate change. Financing incentives were declared by the IFC and Bangladesh Bank to encourage commercial banks to engage with environmentally friendly projects (The Financial Express 2009). Furthermore, the Bangladesh Bank issued a circular identifying a number of priority areas for CSR (Bangladesh Bank 2008). ${ }^{14}$ Although adoption of the CSR guidelines is voluntary, the central bank mentioned that these would be taken into consideration when evaluating banks' performance (Bangladesh Bank 2008). The Bangladesh government also set out fiscal incentives for CSR expenditure for all public limited companies. For instance, companies are allowed to claim a tax rebate of ten per cent of CSR expenditures (GoB 2009).

The ruling party subsequently extended the scope of the rebate in 2011, issuing a new government directive which includes three new areas of CSR activities qualifying for CSR tax rebates: donations to the Liberation War Museum,

\footnotetext{
14 Priority areas include financing programmes to encourage biomass and solar power projects, credit programmes for the diversified production of crops, programmes to support the prompt delivery of remittances from migrant workers and programmes to finance folk arts, music and crafts (Section 1.2, DoS circular no 01, 1 June 2008, Bangladesh Bank).
}

donations to the Father of the Nation memorial and contributions to the prime minister's Education Fund. ${ }^{15}$ Interestingly, the first two items were pre-election commitments. The following section presents a descriptive account of disclosures by segment and scrutinises likely links with politics.

\section{Disclosures by Segment}

Bangladesh Bank produces a yearly review of CSR disclosures made by commercial banks in Bangladesh. Table 2 Panel A presents data for 2008 to 2011. A significant proportion of the banks' CSR disclosures were devoted to the education, health, disaster management, arts and culture, and sports sectors. There were significant successive increases in the CSR disclosures of the banks in 2009 and 2010 and a slight decrease in 2011. In 2011, total CSR expenditure amounted to $2.40 \%$ of after tax profits. ${ }^{16}$ The most significant increase in CSR disclosures was in 2010, when CSR expenditures experienced a three-fold increase compared with 2009. To investigate this further, we examined the classification of CSR disclosures by segment for 2010. Table 2 Panel B ranks the CSR segments in terms of the relative increase in CSR expenditure in a particular segment compared with 2009.

The greatest increase in 2010 was observed in the arts and culture segment. This phenomenal increase was triggered by donations for the Liberation War Museum presented in the arts and culture category. The Liberation War Museum was established in 1996 but its support became an election promise of the ruling party during the election in 2009. Apart from donations made to the Liberation War Museum, several banks also made significant grants to organisations and individuals with explicit political links (examples included donations to children's foundations and football clubs named after family members of the ruling party, and donations towards preparing a documentary and a book on the life of the current prime minister's father, who led Bangladesh to independence).

The second highest increase in CSR spending in 2010 was on sport. However, this is mainly attributable to donations made to the government for organising the South Asian Federation Games, hosted by Bangladesh in 2010. Nevertheless, some banks also sponsored various sports bodies in Bangladesh, and two banks made donations to

\footnotetext{
15 In 2009, the Bangladesh government issued a regulatory order identifying 17 items that would qualify as CSR activities (SRO 270Law/2009, 15 January 2009, Government of Bangladesh). This was later replaced by SRO 229-Law/Income tax/2011 which included three more items.

16 This compares well with average CSR spending by FTSE 100 companies in 2011 ( $0.5 \%$ of pre-tax profits).
} 
Table 2 Distribution of CSR expenditure

\begin{tabular}{|c|c|c|c|c|}
\hline \multicolumn{5}{|c|}{ Panel A: Distribution of CSR expenditure by segment (in million Taka) } \\
\hline & 2008 & 2009 & 2010 & 2011 \\
\hline Disaster relief & 58.6 & 125.1 & 460.41 & 188.03 \\
\hline Education & 30.5 & 94.8 & 400.79 & 612.88 \\
\hline Health & 112.1 & 245.5 & 689.07 & 520.42 \\
\hline Sport & 49.8 & 1.2 & 265.23 & 359.07 \\
\hline Arts and culture & 0.8 & 0.3 & 328.91 & 171.52 \\
\hline Other & 158.9 & 86.9 & 125.58 & 198.73 \\
\hline Total & 410.70 & 553.80 & 2329.8 & 2188.3 \\
\hline$\%$ increase on previous year & & 34.84 & 320.69 & -6.07 \\
\hline \multicolumn{5}{|c|}{ Panel B: Change in 2010 by segment } \\
\hline \multicolumn{4}{|c|}{$\%$ increase } & Rank \\
\hline Disaster relief & & 268 & & 4 \\
\hline Education & & 322 & & 3 \\
\hline Health & & 180 & & 5 \\
\hline Sport & & 22,002 & & 2 \\
\hline Arts and culture & & 109,536 & & 1 \\
\hline Others & & 44 & & 6 \\
\hline
\end{tabular}

Source: Annual review of CSR expenditure, Bangladesh Bank, 2008, 2009, 2010, 2011 sports clubs with explicit political links. For instance, Jamuna Bank and UCBL made donations to newly established football clubs named after two brothers of the incumbent prime minister.

The third highest increase was on the education sector. This spending was mainly for scholarship programmes for schools and universities in various parts of the country. However, a significant chunk of CSR expenditure in this segment went to comparatively well-off schools, universities and hospitals in Dhaka. Further investigation of these CSR disclosures revealed that some of these institutions are located in the home areas of members of parliament and key board members mainly supporting the ruling party.

Disaster relief also increased. The most significant CSR expenditures in the disaster management segment involved the payment of compensation for the Nimtoli and BDR tragedies. In addition, a number of banks made significant donations to the prime minister's relief fund for victims of the 2009 cyclone. This also explains the sudden increase in 2010 in CSR spending on disaster management programmes. On the face of it, these donations do not appear to be politically charged, but the promotional campaign of their contributions does indicate the political use of CSR disclosures. For instance, in most cases, reports of CSR activities in this segment involved the publication of a photograph of the bank's chairman handing over a cheque to the prime minister. Public displays of connections with the prime minister and the ruling party are significant for corporations, as will be discussed later.

Similar trends are found in the health and education sector. Several banks made donations towards infrastructural development in established private hospitals owned by powerful political leaders. Donations were also made to organisations owned by or closely associated with ministers and political leaders. For instance, IFIC bank donated one million Taka (approximately US\$12,700@78.85 per US\$) to an eye hospital owned by the prime minister's health advisor. Al Arafah Bank has an English-medium school named "Al Arafah International School"; the National Bank has established a school named "National Bank Public School" in Dhaka; and Prime Bank has sponsored a student studying in North South University, an expensive private university in Dhaka.

The "other" segment includes CSR expenditures such as investment in environmentally friendly banks. Disclosures in this area were vague, and although a number of banks mentioned policies regarding "green banking", no specific examples of such actions were disclosed. Some banks disclosed the financing of fuelling stations as CSR activities, although these appear to have been profit-making ventures. Some banks also made grants towards the "beautification" of Dhaka-a government initiative in which major corporations are given responsibility for maintaining parks in specific locations. 
These donations can be seen as philanthropic ventures. It may also be argued that they do not necessarily concern wider stakeholders and local communities but focus firmly on the ruling party and its leaders. Bangladesh is one of the countries most vulnerable to the effects of global climate change. Sea levels are projected to rise by $20 \mathrm{~cm}$, which will seriously threaten the livelihoods of the Bangladeshi population (NY Times 2014). A Bangladesh Bank (2008) guideline identifies this as a priority area, and a tax incentive has also been put in place; yet, the banks do not appear to have engaged in any meaningful way. For instance, two banks appear to mention it in their reports, and ten banks announced the creation of risk funds in 2010 . Nevertheless, no tangible CSR spending was reported by any of the banks during the study period. In contrast, we see an exponential increase of CSR disclosure items favoured by the ruling party.

Table 3 presents the most frequent CSR disclosure items (four of them) by banking companies in Bangladesh between 2009 and 2012. Table 4 lists some infrequent or one-off CSR disclosure items. ${ }^{17}$ The disclosures most frequently reported under CSR were financial assistance to family members of victims of the Bangladesh Rifles revolt (classified as "disaster management"), followed by donations to the Liberation War Museum (classified as "art and culture"), donations to victims of the Nimtoli fire tragedy (classified as "disaster management") and contributions to autism causes (classified as "health"). These disclosure items were not only frequent but also the largest CSR cost items reported in annual reports. Two recurring patterns/ themes emerged from the CSR disclosure items described above-contributions supporting the ruling party's agendas and contributions to the personal projects of leaders. The following section discusses these two themes in the context of four key disclosure items.

\section{Contributions Supporting the Ruling Party Agendas}

The two most frequent disclosure items in relation to the ruling party's agendas will be discussed below. This is to illustrate why such items are deemed to be of a political nature and support the ruling party's agendas rather than corporate philanthropic activities.

\footnotetext{
$\overline{17}$ This table is by no means an exhaustive list of one-off/infrequent disclosure items. We present these items to demonstrate ways in which banking companies use corporate social disclosures.
}

\section{Donations Made to the Liberation War Museum}

Between 2009 and 2012, there were 19 instances of donations made by the sampled banking companies to the Liberation War Museum in Dhaka. The minimum disclosed donation was Taka 0.50 million and the maximum was Taka 10 million in a year. It should be mentioned that the ruling party claims itself to be a pro-liberation force and brands its opposition as an anti-liberation force. Finding a permanent home for the Liberation War Museum was an election promise of the ruling party. Construction of the museum started during the 1996-2001 tenure of the current government but was subsequently stalled by the succeeding government. In order to meet its pre-election commitments, the government needed to complete it before 2014, when the next general election was due. ${ }^{18}$ Soon after the election of the current government in 2009, banks began to make donations to the prime minister in aid of the Liberation War Museum (UNB 2010; The Daily Star 2010c). Notably, in June 2011, the government included donations to the Liberation War Museum on a list of CSR activities (classified as "art and culture") qualifying for tax exemption (GoB 2011).

Corporate donations to arts and culture are very common in countries such as the UK and the USA and rarely articulated as a politically motivated CSR activity in the literature (Campbell et al. 2002; Moore 1995). For several reasons, contributions to war museum might be articulated as a politically motivated CSR activity in our case. First, donating to museums was not a usual CSR activity, given that these banks had no history of contributing to any museums. Banks' interests in the Liberation War Museum are noteworthy, as is the fact that most banks made exactly the same donation for this specific purpose. For example, Southeast Bank, EBL, IFIC Bank and Al Arafah Bank all reported a donation of Taka 0.50 million as a contribution towards the construction of the Liberation War Museum. It might be argued that this was perhaps to gain tax exemptions, but donations began even before the tax advantage was put in place. Second, donations were made and disclosed in a particular way, for instance photographs with the prime minister showing donations of money to the Liberation Museum in annual reports, as well as newspaper publicity. These public displays of contributions signal that the banks sought to gain or strengthen political ties with the ruling party from this particular CSR activity. A similar

\footnotetext{
${ }^{18}$ An election was held without the participation of the major opposition party. Before the election, the heads of two dynastiesKhaleda Zia and Sheikh Hasina-bickered face-to-face over the format of the elections. After the election, the situation deteriorated further, taking the general population hostage with strikes, shutdowns and political violence.
} 
Table 3 Most frequent CSR disclosures

\begin{tabular}{ll}
\hline Item & Frequency \\
\hline Donation to Liberation War Museum & 19 \\
Donation to BDR tragedy & 17 \\
Donation to victims of Nimtoli & 16 \\
Contributions to autism causes & 14 \\
\hline
\end{tabular}

feature appeared in other CSR disclosure items, as presented below.

\section{Financial Assistance to Victims of the Bangladesh Rifles (BDR) Revolt}

On 25 February 2009, a mutiny by a section of BDR personnel resulted in the killing of 74 victims, including 57 army officers. The incident received worldwide media attention, and the government was criticised for its failure to limit the number of casualties. The ruling party, already lacking a strong relationship with the armed forces compared with that of its rival-Bangladesh Nationalist Party (BRAC 2008), was blamed for its inept handling of the entire incident (The Economist 2009). The main rival party also led by a family accused the government of plotting the incident. The government tried to make amends by announcing generous financial packages for family members of the victims (The Financial Express 2009).

Not surprisingly, donations to the government to help the families of victims of the BDR incident became a recurrent "CSR" activity reported by the sampled banks. For instance, the annual report of Southeast Bank (2012) disclosed.

Following the tragic incident of brutal killing of valiant army officers at the then BDR headquarters,
Southeast Bank pioneered an idea to stand by the affected families. In accordance with our devised formula, the bank, in collaboration with the Government of Bangladesh, selected seven bereaved families of the Shaheed (meaning "martyred") army officers who embraced martyrdom at the carnage at the BDR headquarters to stand by them. Each family is being given Taka forty thousand per month totalling Taka 0.48 million in a year. The contribution for the year 2012 was made through the honourable Prime Minister amongst the recipients (Southeast Bank Annual Report 2012, p. 106).

Donations by corporations to such tragedies are common in many settings, perhaps demonstrating their philanthropic activities to appease wider stakeholders. We would argue that these CSR disclosures have political motivations for two reasons. First, the way in which donations were made to the victims is noteworthy. None of the banks chose to make direct donations to families of the BDR victims but opted to transfer money via the government (or in the presence of the prime minister). Second, the way in which the activities were disclosed in annual reports is quite revealing. Often, the banks' annual reports contained photos of the bank chairman handing over a cheque to the prime minister. In addition, photographs of banks' donations to BDR victims given directly to the prime minister were widely publicised in newspapers (Daily Sun 2012).

Both of these contributions to enhancing the ruling party's position in wider society can be seen as attempts to connect with the political leadership of the country perhaps to seek out new ties and/or manage existing relationships. This might be at the expense of other stakeholders, such as employees or clients, or of other pro-poverty projects that might otherwise have deserved priority. Therefore, by

Table 4 Some infrequent/one-off CSR disclosures

\begin{tabular}{|c|c|c|}
\hline Disclosure items & Names of banks & Political links \\
\hline Donation to freedom fighter memorial & Bank Asia & $\begin{array}{l}\text { Current Regime's political } \\
\text { commitment }\end{array}$ \\
\hline Donation to Father of the Nation memorial trust & Dutch Bangla bank & $\begin{array}{l}\text { The current PM is the daughter of } \\
\text { Father of the Nation }\end{array}$ \\
\hline $\begin{array}{l}\text { Donation to children's foundation/football clubs named after family } \\
\text { members of the Prime Minister }\end{array}$ & $\begin{array}{l}\text { Rupali Bank (SCB), } \\
\text { Jamuna Bank, ICBL }\end{array}$ & Prime Minister's Kin \\
\hline $\begin{array}{l}\text { Financial assistance for publishing book and producing a documentary on } \\
\text { the life of the Father of the nation }\end{array}$ & $\begin{array}{l}\text { Southeast Bank, Rupali } \\
\text { Bank (SCB) }\end{array}$ & $\begin{array}{l}\text { The current PM is the daughter of } \\
\text { Father of the Nation }\end{array}$ \\
\hline Donation to hospital owned by the health minister & IFIC Bank & Current ruling regime \\
\hline Donation to schools in the electoral constituency of the Prime Minister & $\begin{array}{l}\text { Basic Bank, Mercantile } \\
\text { Bank }\end{array}$ & Prime Minster \\
\hline Daylight Savings Campaign & UCBL & Prime Minster's project \\
\hline Donation for advertisement for Prime Minister's South-South award & Southeast Bank & Prime Minister \\
\hline
\end{tabular}


making donations to the Liberation Museum or the BDR tragedy in the guise of CSR activities, the bank managers fostered trust from the ruling party.

\section{Contributions to Personal Projects of Leaders}

Tables 3 and 4 also report items which are directly associated with the personal projects of powerful leaders in the ruling party. Infrequent or one-off items such as donations to children's foundations or football clubs named after family members of the prime minister, a donation to a hospital owned by the health minister, and donations to schools in the electoral constituency of the prime minister are clearly related to personal projects. The two most frequently reported disclosure items associated with personal projects will be discussed below to illustrate why these items are deemed to be of a political nature.

\section{Donations to Victims of the Nimtoli Tragedy}

On 3 June 2010 a tragic fire in Nimtoli, a densely populated part of Dhaka, the capital of Bangladesh, killed 116 victims. Owing to the gravity of the incident and its politically sensitive location (in an electoral constituency held by the ruling party), it received huge media publicity. The media reported as a side-line the tragic event of two sisters who were due to get married on that day but lost their families in the fire. This news also attracted significant media attention and the prime minster announced that she would take responsibility for making the wedding arrangements for the two sisters. Accordingly, the wedding ceremony was arranged at the prime minister's official residence on 9 June, and pictures of the brides, with the prime minister, appeared on the front pages of every major newspaper in the country (The Daily Star 2010a). With banks' assistance (Rupali Bank in particular), the prime minister handed over Taka 100,000 to each of 98 affected families (The Daily Star 2010b). Rather than making donations directly to the victims, most banks chose to make such donations through the prime minister's relief fund. As EBL's annual report (2010 p. 94) states: "EBL contributed Taka 0.5 million to the prime minister's relief fund as a donation for the Nimtoli victims".

In an address to parliament, the prime minister also asked for donations for the Nimtoli tragedy. Although less significant than other natural calamities that occur frequently in Bangladesh, the tragedy received huge attention owing to the involvement of key political figures. Financial grants were made by the banks and reported in their annual reports as "to brides in the presence of the PM as a token of compassion towards them" (Rupali Bank Annual Report 2010).
Although in this particular tragedy the prime minister made a personal plea, it is not uncommon for corporations to contribute to local issues. Previous studies located in non-traditional settings have argued that corporations focus on giving to local communities (Campbell et al. 2002; Porter and Kramer 2002). On the face of it, this may sound very natural and apolitical. Nevertheless, we would argue for two reasons that the way in which donations are made and disclosed in annual reports is political in nature. First, while corporations have a responsibility to contribute to the community or to victims of accidents, in this scenario direct contributions to the victims were needed, but instead bankers chose to contribute through the ruling party leader. Second, the banks in question had not previously donated to any disaster programmes before this incident. This is interesting because fire tragedy is unfortunately not uncommon in Bangladesh, yet the donations raised, disclosed and publicised for this particular tragedy were unique.

\section{Donations Made to Autistic Children}

Donations to autistic children (classified under CSR activities in the education sector) were a particularly recurrent feature of CSR disclosures by banking companies in 2012. Interestingly, on all ten occasions on which such donations were made, the contributions went to a particular school named "Proyash", run by the Bangladesh Army. Donations to autistic children are undeniably a noble humanitarian cause, and should be appreciated and encouraged. However, a particular point of concern in these cases was the involvement of the prime minister's daughter who, in 2011, was appointed the chair of the autism advisory committee to the government of Bangladesh. Subsequently, several high-profile events were organised by the government, attended by the prime minister herself along with her daughter. Notably, the only bank that made donations to Proyash in all 4 years was Trust Bank-a bank run by the Bangladesh Armywhereas for the other banks it appeared to be a one-off payment. Contributions to the autism cause increased following the appointment of the prime minister's daughter.

In addition to the above most frequent disclosure items, banks disclosed and publicised a number of other social activities directly linked with the current prime minister and her kin. For instance, expenditure on advertising the prime minister's achievements, such as receiving a "South-South" award (ICT development award), was designated as CSR activity in Southeast Bank's annual report. Donations were also made by the same bank towards highlighting the image of Bangabandhu-the father of the nation (SEBL annual report 2012, p. 108). Similarly, Basic Bank declared donations to educational 
institutions in Gopalganj district, the prime minister's electoral constituency, "on behalf of the prime minister" (Basic Bank 2012). UCBL (2012) reported that they were the "only company to support the government's daylight savings campaign", widely believed to be the idea of the prime minister.

Clearly, contributions to the prime minster's favourite projects seem to be the most popular CSR activities for banks. Over the 4 years, all sampled banking companies, as part of their CSR activities, posted at least one photograph showing their chairmen handing over cheques to the prime minister as donations. These CSR activities included mainly projects that the prime minister, her kin and fictive kin had endorsed at national and local levels (see Tables 3 and 4). Several banks made photographs with the prime minister a recurring annual theme in their CSR reports. The annual report of one commercial bank (Standard Bank) actually referred to the prime minister as the jananetri (meaning "leader of the masses") — a political term used only by members of the Awami League to refer to their leader.

Overall, our empirical analysis suggests that the central bank's measures to influence banks' CSR activities seem to have limited impact. Environmentally friendly projects and other incentivised areas of investment have not taken off. Banks do not seem to be interested in taking advantage of fiscal regulations unless CSR activities are connected with the ruling party. The absence of any reference to global standards, such as the IFC's framework and the GRI, is noteworthy. The banks have neither adopted nor implemented the IFC's suggested social and environmental performance frameworks, nor have they considered GRI as their reporting framework (also reported in Khan et al. 2011). This contrasts sharply with the idea that political CSR is a consequence of "globalisation". Instead, this suggests that political CSR is crucially dependent on state politics. In the case of Bangladesh, state politics are a tug of war between two family-led political parties.

\section{Discussion}

Theoretically, this study sought to develop a broader understanding of the political perspectives of CSR disclosures in traditional settings drawing on Weber's notion of "traditionalism". Following the Weberian methodologies, this paper has examined the historical and political conditions of Bangladeshi society, showing that social and political lives are heavily influenced by family culture. Not surprisingly, we have found the strong presence of familyled political parties. The current prime minister is the daughter of the founder of the ruling party. Family kin and fictive kin are the powerful leaders of the party. Heredity politics are the backbone of Bangladeshi democracy, and ultimate accountability seems to lie with family, exhibiting features of traditionalism in action. Politics pursued by the two leading political parties have also led to the creation of a culture that many businessmen believe actively seeking and maintaining political ties will help them expand their business.

We have found that all banks adopted politically charged disclosure strategies. We have examined whether elements of traditionalism provide deeper insights into politically charged CSR disclosures reported by banking companies in Bangladesh. Several key elements of traditionalism appear to constitute traditional societies, including personal loyalty and the public display of loyalty, the master-servant relationship, and obedience to personal rather than formal authority. We have demonstrated that these elements of traditional societies provide an understanding of why banks (with or without explicit political linkages with the ruling party) have deployed a particular form of CSR disclosure strategy.

Banks have clearly ignored Bangladesh Bank (2008)'s priority area of CSR and tax incentivised CSR items but rather focused on disclosures associated with the personal projects of leaders or the ruling party agendas. Viewed through a Weberian lens, it is understandable why companies devote significant effort to individuals rather than wider stakeholders. Family and chief (head of the family), kin, fictive kin and relatives are the essential fabric of traditional society. Thus, it is unsurprising to see CSR directed towards individual or family. Traditionalism drives a subject to be loyal to the chief in order to be seen to be trustworthy (Weber 1947). These elements of traditionalism become more apparent when we examine in greater detail some of the key disclosure items during the 4-year period.

We have demonstrated that four key disclosure items such as donations to Liberation Museum, financial assistance to victims of the BDR revolt and Nimtoli fire tragedy and donations to the cause of autistic children are politically motivated. These donations either promoted ruling party's agendas or powerful leaders' personal projects. We argue that underlying conditions of traditional societies have enthused banking companies to select suitable disclosures to seek out and strengthen political ties with the ruling party. For instance, contributions to BDR victims and Liberation Museum by banking companies can be seen as a way of enhancing the ruling party's position in wider society. From the banks' point of view, failure to make such donations might jeopardise the master-servant relationship. Therefore, by making donations to the Liberation Museum or the BDR tragedy in the guise of CSR activities, the bank managers fostered trust from the party. Those donations were very well publicised by the companies in 
the annual reports and newspapers. Such public displays of loyalty by banks are consistent with Weber's (1947) definition of a traditional society, in which domination, exercised by an individual or a family, is based primarily on relations of personal loyalty. This is also a perfect demonstration of how to serve the "master", in the Weberian sense, in difficult times.

Contributions to personal projects such as donations to autism cause or Nimtoli fire tragedy may appear to be usual corporate philanthropic activities. We have argued that they were more than just appeasing the wider stakeholders; the donations were made as a vehicle to demonstrate loyalty to the person in authority. In a traditional society, as expected, individual economic units are geared primarily towards satisfying the needs and preferences of the "master" or family/clan (Dyball and Valcarcel 1999). It is rational for banks to engage in CSR activities particularly favoured by the ruling family, while the needs and preferences of state institutions fail to attract the same attention. As Weber (1968) states, the "master" is expected to do good turns, governed by an ethical sense of equity or of utilitarian expediency. That the "master" looks after his "subjects" is clearly evidenced by the fact that many bankers receive benefits in the form of business or political opportunities when they arise. For bankers, it is much more materially significant to serve political masters rather than complying with global standards for CSR disclosures or taking advantage of central bank incentives.

Donations to personal projects were also publicly displayed in media and newspapers. In Weber's terms, this public display of loyalty to the ruling family puts companies in good stead: "Obedience is not owed to enacted rules, but to the person who occupies a position of authority... who has been chosen for such a position" (Weber 1947, p. 341). Banks in Bangladesh not only sought to disclose CSR activities in their annual reports but also went further, such as printing photographs in public media, and handing cheques to political leaders rather than spending directly on communities. This has happened especially where low-level disclosures of corporate affairs are the norm (Uddin and Choudhury 2008). Public displays of political connections seem to be more important in Bangladesh than the low-profile donations of investment bankers ${ }^{19}$ to political parties common in the Western world. Fuller explanations of these types of corporate conduct require the notion of traditionalism to be invoked. We would argue that the underlying nature of politically charged corporate disclosures is rooted in traditional attitudes such as personal loyalty, comradeship and the

\footnotetext{
${ }^{19}$ For instance, Barack Obama has received US $\$ 3.4$ million in campaign contributions from investment banks alone, while George Bush received about US $\$ 2.5$ million (www.influenceexplorers.com).
}

master-servant relationship. In Weberian terms, the institutions of the community, market and state are conjoined in traditional societies, making the institutions of family and clans powerful and enduring.

In an ideal/rational setting, the state plays the conventional roles of controller, provider of external infrastructure and receiver of levies (Fassin and Gosselin 2011), and is responsible for creating accountability in the financial sector. In a traditional setting, the state or state-like bodies are overpowered by family and their kin. Bankers draw power from the ruling party and are often able to ignore/ avoid rational measures introduced by state bodies such as the central bank in Bangladesh. Actors within the company are not always necessarily related to families leading the political parties, but manage to exploit the familial relationships of the political parties. This observation is in line with previous studies on accounting practices in traditional societies (Uddin 2009; Dyball and Valcarcel 1999). Mannan (1992) argues that political parties maintain loyal supporters in various positions within the institution and thereby personalise state bodies. Thus, banks have little interests to appease wider stakeholders given the nature and power of the state and state-like bodies. This is much more convenient for banks to focus on political leaders, parties and families. Corporation's wider stakeholder legitimacy for CSR is very weak in Bangladesh.

We argue that it is unsurprising that bankers use disclosures to demonstrate their loyalty to the family in power as this is seen as the ultimate accountability. Accountability to the wider public or state bodies is seen as formal and symbolic, whereas loyalty to individuals and families in power is real. Banks are seen more as a household, in which disclosure is considered to be revealing the family's secrets. Yet, in this secretive world, the fact that banks are lining up to disclose specific social activities is quite revealing. Disclosure within the family or to the master (in this case the family in power) has greater value than disclosure for legal reasons. We argue that traditionalism is at work here, weakening rational guidelines for disclosure.

\section{Conclusions}

This paper concludes by considering the research questions set out earlier. Do corporations in traditional settings exploit CSR disclosures to seek out and manage political ties and, if so, how? How do we explain the political nature of CSR disclosures? This paper has drawn on the Weberian notion of "traditionalism" to shed light on the nature of CSR disclosures made by banks in Bangladesh.

The study has examined the nature of and changes to CSR between 2008 and 2010. We found that, in the banking companies over the period of study, apparently 
neutral, corporate, philanthropic activities disclosed and promoted in CSR reports are inextricably linked to powerful leaders' personal projects and the ruling party's agendas. For instance, contributions to the Liberation War Museum suddenly appeared in company accounts, and bankers (owner-managers) were lined up to contribute to the prime minister's relief funds for tragic events such as the BDR mutiny and the Nimtoli fire tragedy, making donations to the prime minister's brother's memorial fund, and even funding a biography of the prime minister's father.

Theoretically, we have argued that the emergence of politically charged CSR disclosures provides new insights if examined in the context of the political regime and traditionalism. We have discussed historical and political conditions in Bangladesh to understand the development of Bangladeshi society and the dominance of the ruling party in economic and political affairs. We have demonstrated elements of traditional societies, including personal loyalty and the public display of loyalty, the master-servant relationship, and obedience to personal rather than formal authority, provide an understanding of politically charged disclosures by banks.

The paper makes several contributions. First, the paper contributes to disclosure studies where political motivations of corporate disclosure rarely discussed. The paper specifically contributes to the critical tradition in political CSR research. Drawing on disclosures, the paper demonstrates that corporations' disclosure patterns are significantly dependent on seeking and maintaining ties with the ruling party. Although not involving CSR, similar corporate behaviour is reported in Dieleman and Boddewyn's (2012) work. This also runs contrary to the established normative understanding of the political roles of corporations (Scherer et al. 2006, 2009).

Second, the paper extends the debate on political CSR by demonstrating that the role of family and familial values at the organisational and national levels can be very important when it comes to CSR disclosure and activities in societies that share characteristics with Weber's understanding of traditionalism. The Weberian notion of traditionalism is useful in understanding the complex links between politics and families and their influence on corporate practices such as CSR. This notion of the power of a family-led state over corporations does not chime with the idea of the diminished role of the state (whether familial or not) and the political CSR activities of corporations (Scherer and Palazzo 2011), but offers support for work by Whelan and his colleagues (Whelan 2012; Whelan and Muthuri forthcoming), who argue that pressures at the national and intra-organisational level are often much more significant than transnational pressures in promoting and enforcing CSR standards. The paper questions the idea of stakeholder legitimacy for corporations in traditional settings contrary to 'mainstream' political CSR writings that concern with wider stakeholders would be considered 'legitimate' globally.

Finally, this paper has opened the way to further research on politically motivated CSR studies in both developed and traditional societies. It would be useful to examine cross-cultural studies on CSR disclosures, linking them with political motivations, human rights, bribery and corruption. It has also been suggested that CSR activities and disclosures vary with different legal, political and economic contexts across countries. One aspect of these differences may be the way in which domestic regulatory regimes have historically been shaped by colonial regimes. Weberian concepts such as rationality versus traditionalism may help shed light on differences in corporate social behaviour in different contexts. We need to gain a better understanding of the role of familial relationships and traditions in broader governance issues, including CSR disclosures, in relation to corruption and human rights, especially in traditional societies. These areas, though important, remain under-investigated and under-theorised.

Open Access This article is distributed under the terms of the Creative Commons Attribution 4.0 International License (http://crea tivecommons.org/licenses/by/4.0/), which permits unrestricted use, distribution, and reproduction in any medium, provided you give appropriate credit to the original author(s) and the source, provide a link to the Creative Commons license, and indicate if changes were made.

\section{References}

Bangladesh Bank. (2008). Mainstreaming corporate social responsibility in banks and financial institutions in Bangladesh, DOS circular no. 1. Department of Off-site Supervision, Dhaka.

Bebbington, J., Larrinaga-Gonzalez, C., \& Moneva, J. (2008). Corporate social reporting and reputation risk management. Accounting, Auditing and Accountability Journal, 21(3), 337-361.

Beck, T., Demirgüç-Kunt, A., \& Levine, M. S. (2011). Bank financing for SMEs: Evidence across countries and bank ownership types. Journal of Financial Services Research, 39(1-2), 35-54.

BEI. (2004). The code of corporate governance for Bangladesh: Principles and guidelines for best practices in the private sector, financial institutions, state-owned enterprises and non-governmental organizations (pp. 1-85). Dhaka: Task Force on Corporate Governance, Bangladesh Enterprise Institute.

Belal, A., \& Roberts, R. W. (2010). Stakeholders' perceptions of corporate social reporting in Bangladesh. Journal of Business Ethics, 97(6), 311-324.

Berglöf, E., \& Claessens, S. (2006). Enforcement and good corporate governance in developing countries and transition economies. The World Bank Economic Review, 21(1), 123-150.

BRAC. (2008). The state of governance in Bangladesh: Confrontation, competition, accountability. Dhaka: Institute of Governance Studies, BRAC University.

Byrch, C., Milne, M. J., Morgan, R., \& Kearins, K. N. (2015). Seeds of hope? Exploring business actors' diverse understandings of 
sustainable development. Accounting, Auditing \& Accountability Journal, 28, 671-705.

Campbell, D. J., \& Abdul Rahman, M. R. (2010). A longitudinal examination of intellectual capital reporting in Marks \& Spencer annual reports, 1978-2008. The British Accounting Review, 42(1), 56-70.

Campbell, D., Moore, G., \& Metzger, M. (2002). Corporate philanthropy in the UK: 1985-2000, some empirical findings. Journal of Business Ethics, 39(1-2), 29-41.

Caramanis, C. V. (2005). Rationalisation, charisma and accounting professionalisation: Perspectives on the intra-professional conflict in Greece, 1993-2001. Accounting, Organizations and Society, 30(3), 195-221.

Chapple, W., \& Moon, J. (2007). Introduction: CSR agendas for Asia. Corporate Social Responsibility and Environmental Management, 14(4), 183-188.

Chua, W. F., \& Poullaos, C. (1998). The dynamics of 'closure' amidst the construction of market, profession, empire and nationhood: A historical analysis of an Australian Accounting Association, 1886-1903. Accounting, Organizations and Society, 23(2), 155-187.

Cooper, S. M., \& Owen, D. L. (2007). Corporate social reporting and stakeholder accountability: The missing link. Accounting, Organization, and Society, 32(7-8), 649-667.

Crane, A., Matten, D., \& Moon, J. (2008). Corporations and citizenship. Cambridge: Cambridge University Press.

Daily Sun. (2012). PM hands over cheques to family members of slain army officers. Retrieved March 1, 2012, from http://www.dailysun.com.

Deegan, C. (2002). Introduction-The legitimising effect of social and environmental disclosures-A theoretical foundation. Accounting, Auditing and Accountability Journal, 15(3), 282-311.

Deegan, C. (2014). Financial accounting theory (4th ed.). Sydney: McGraw-Hill.

Deegan, C., \& Blomquist, C. (2006). Stakeholder influence on corporate reporting: An exploration of the interaction between WWF-Australian and the Australian minerals industry. Accounting, Organizations and Society, 31(4-5), 343-372.

Dhaliwal, D. S., Lee, O. Z., Tsang, A., \& Yong, G. Y. (2011). Voluntary non-financial disclosures and cost of equity capital: The initiation of corporate social responsibility reporting. The Accounting Review, 86(10), 59-100.

Dieleman, M., \& Boddewyn, J. (2012). Using organization structure to buffer political ties in emerging markets: A case study. Organization Studies, 33, 71-95.

Dyball, M. C., Chua, W. F., \& Poullaos, C. (2006). Mediating between colonizer and colonized in the American empire: Accounting for government monies in the Philippines. Accounting, Auditing \& Accountability Journal, 19(1), 47-81.

Dyball, M. C., \& Valcarcel, L. J. (1999). The 'rational' and 'traditional': The regulation of accounting in the Philippines. Accounting Auditing and Accountability Journal, 12(3), 303-328.

Fassin, Y., \& Gosselin, D. (2011). The collapse of a European bank in the financial crisis: An analysis from stakeholder and ethical perspectives. Journal of Business Ethics, 102(2), 169-191.

GoB. (2009). Tax rebate on corporate social responsibility expenditures. SRO 270-Law/2009, National Board of Revenue, Government of Bangladesh, Dhaka.

GoB. (2011). Tax rebate on corporate social responsibility expenditures. SRO 229-law/Income tax/2011 replacing SRO 270-Law/ 2009, National Board of Revenue, Government of Bangladesh, Dhaka.

Gu, H., Ryan, C., Bin, L., \& Wei, G. (2013). Political connections, guanxi and adoption of CSR policies in the Chinese hotel industry: Is there a link? Tourism Management, 34, 231-235.
Guthrie, J., \& Parker, L. (1989). Corporate social reporting: A rebuttal of legitimacy. Accounting and Business Research, 19(6), $343-352$

Hackston, D., \& Milne, M. (1996). Some determinants of social and environmental disclosures in New Zealand companies. Accounting, Auditing and Accountability Journal, 9(1), 77-108.

Hart, K. (1982). The political economy of West African agriculture (pp. 1-226). Cambridge: Cambridge University Press.

Hegde, P., Bloom, R., \& Fuglister, J. (1997). Social financial reporting in India: A case. The International Journal of Accounting, 32(2), 155-172.

Higgins, C., Milne, M. J., \& Van Gramberg, B. (2014). The uptake of sustainability reporting in Australia. Journal of Business Ethics, 129, 445-468.

Hopkins, A. G. (1976). Imperial business in Africa-Part 1. The Journal of African History, 17(01), 29-48.

Hsieh, N. H. (2009). Does global business have a responsibility to promote just institutions? Business Ethics Quarterly, 19(2), 251-273.

Humphrey, C. (1987). Privatization in Bangladesh. Centre for Privatization, US Agency for International Development, Washington DC.

Hyden, G. (1983). No shortcuts to progress: Africa development management in perspective. London: Heinemann.

Islam, M. A., \& Deegan, C. (2008). Motivations for an organisation within a developing country to report social responsibility information: Evidence from Bangladesh. Accounting, Auditing and Accountability Journal., 21(6), 850-874.

Islam, M. A., Dissanayake, T., Dellaportas, S. \& Haque, S. (2016). Anti-bribery disclosures: A response to networked governance. Accounting Forum. doi:10.1016/j.accfor.2016.03.002.

Jaggi, B., \& Zhao, R. (1996). Environmental performance and reporting: Perceptions of managers and accounting professionals in Hong Kong. The International Journal of Accounting, 31(3), 333-346.

Katzenstein, P. (1985). Small states in world markets. Ithaca, NY: Cornell University.

Khan, A. A. (1986). Handling of industrial disputes in the public sector industries in Bangladesh. Unpublished Ph.D. Thesis, University of Glasgow.

Khan, M. H. U. Z., Islam, M. A., Fatima, J., \& Ahmed, K. (2011). Corporate sustainability reporting of major commercial banks in line with GRI: Bangladesh evidence. Social Responsibility Journal., 7(3), 347-362.

Khan, M. M. (2003). State of governance in Bangladesh. The Round Table: The Commonwealth Journal of International Affairs, 92(273), 391-405.

Kochanek, S. A. (2000). Governance, patronage, politics and democratic transaction in Bangladesh. Asian Survey, 40(3), 530-550.

Laine, M. (2009). Ensuring legitimacy through rhetorical changes? A longitudinal interpretation of the environmental disclosures of a leading Finnish chemical company. Accounting, Auditing \& Accountability Journal, 22(7), 1029-1054.

Laine, M. (2010). Towards sustaining the status quo: Business talk of sustainability in Finnish corporate disclosures 1987-2005. European Accounting Review, 19(2), 247-274.

Lux, S., Crook, T. R., \& Woehr, D. J. (2011). Mixing business with politics: A meta-analysis of the antecedents and outcomes of corporate political activity. Journal of Management, 37(1), 223-247.

Mahmud, W., Ahmed, S., \& Mahajan, S. (2008). Economic reforms, growth and governance: The political economy aspects of Bangladesh's development surprise. Washington, DC: The World Bank.

Mannan, M. (1992). An anthropology of power-structure: The making of tribunes and dictators in Bangladesh. Journal of South Asian and Middle Eastern Studies, 16(2), 41-54. 
Mannan, M. (2006). Family politics and governance in Bangladesh. The Daily Star, 5(868).

Mannan, M. (2011, June). Governance culture of the ruling elite in Bangladesh. In Dynasty: A symposium on lineage and family ties in sub-continental politics, seminar 622 .

Mathews, M. R. (1997). Twenty-five years of social and environmental accounting research: Is there a silver jubilee to celebrate? Accounting, Auditing \& Accountability Journal, 10(4), 481-531.

Matten, D., \& Moon, J. (2008). Implicit and explicit CSR: A conceptual framework for a comparative understanding of corporate social responsibility. Academy of Management Review, 33(2), 404-424.

McLane, R. J. (1993). Land and local kingship in eighteenth-century Bengal. Cambridge: Cambridge University Press.

Milne, M. J., \& Gray, R. H. (2013). W(h)ither ecology? The triple bottom line, the global reporting initiative, and corporate sustainability reporting. Journal of Business Ethics, 118(1), 13-29.

Momin, M., \& Parker, L. D. (2013). Motivations for corporate social responsibility reporting by MNC subsidiaries in an emerging country: The case of Bangladesh. British Accounting Review, 45(3), 215-228.

Moore, G. (1995). Corporate community involvement in the U.K.Investment or atonement? Business Ethics: A European Review, 4, 171-178.

Murtha, T. P., \& Lenway, S. (1994). Country capabilities and strategic state: How national political institutions affect multinational corporations' strategies. Strategic Management Journal, 15(special issue), 113-129.

Muthuri, J., \& Gilbert, V. (2011). An institutional analysis of corporate social responsibility in Kenya. Journal of Business Ethics, 98(3), 467-483.

NY Times. (2014). Rising sees. Available at http://www.nytimes. com.

Otsuka, H. (1966). Max Weber's view of Asian society. Developing Economies, 4, 275-298.

Owen, D. (2008). Chronicles of wasted time? A personal reflection on the current state of, and future prospects for, social and environmental accounting research. Accounting, Auditing \& Accountability Journal, 21(2), 240-267.

Palazzo, G., \& Scherer, A. G. (2006). Corporate legitimacy as deliberation: A communicative framework. Journal of Business Ethics, 66(1), 71-88.

Parker, L. D. (2005). Social and environmental accountability research: A view from the commentary box. Accounting, Auditing \& Accountability Journal, 18(6), 842-860.

Porter, M., \& Kramer, M. (2002). The competitive advantage of corporate philanthropy. Harvard Business Review, 80, 56-68.

Prechel, H., \& Morris, T. (2010). The effects of organizational and political embeddedness on financial malfeasance in the largest U.S. corporations' dependence, incentives, and opportunities. American Sociological Review, 75(3), 331-354.

Samkin, G., Schneider, A., \& Tappin, D. (2014). Developing a reporting and evolution framework for biodiversity. Accounting, Auditing \& Accountability Journal, 27(3), 527-562.

Scherer, A. G., \& Palazzo, G. (2011). The new political role of business in a globalized world: A review of a new perspective on CSR and its implications for the firm, governance, and democracy. Journal of Management Studies, 48(4), 899-931.

Scherer, A. G., Palazzo, G., \& Baumann, D. (2006). Global rules and private actors: Toward a new role of the transnational corporation in global governance. Business Ethics Quarterly, 16(4), 505-532.

Scherer, A. G., Palazzo, G., \& Matten, D. (2009). Introduction to the special issue: Globalization as a challenge for business responsibilities. Business Ethics Quarterly, 19(3), 327-347.
Siddiqui, J. (2010). Development of corporate governance regulations: The case of an emerging economy. Journal of Business Ethics, 91(2), 253-274.

Siddiqui, J., \& Uddin, S. (2016). Human rights disasters, corporate accountability and the state: Lesson learned from Rana Plaza? Accounting, Auditing \& Accountability Journal, 29(4), 679-704.

Skippari, M. (2005). Intra-firm variation and change in political strategies of a multidivisional firm. International Studies of Management and Organisation, 35(3), 82-110.

Sobhan, R., \& Ahmad, M. (1980). Public enterprise in an intermediate regime: A study in the political economy of Bangladesh. Dhaka: Bangladesh Institute of Development Studies.

The Daily Star. (2010a, June 9). Nimtoli sisters' wedding at Ganabhaban tonight.

The Daily Star. (2010b, June 27). Nimtoli, Begunbari: 98 families get cheques from PM.

The Daily Star. (2010c, August 12). Taka 24 crore support to Liberation War Museum: Its projecting true history of liberation war, says PM.

The Daily Star. (2012, March 9). Central bank gives into political pressure.

The Daily Star. (2015, October 14). Business factor in our politics.

The Economist. (2009, March 5). Bangladesh after the rebellion: Bad or mad?

The Financial Express. (2009, July 1). PM asks private banks to open branches in rural areas.

The Financial Express. (2011, July 25). Political decision behind new private banks.

The Institute of Governance Studies. (2008). The state of governance in Bangladesh in 2007: Expectations, commitments and challenges. Bangladesh: BRAC University.

Tregidga, H., Milne, M. J., \& Kearins, K. (2014). (Re) presenting sustainable organizations. Accounting, Organizations and Society, 39(6), 477-494.

Tsamenyi, M., \& Uddin, S. N. (2008). Introduction to corporate governance in less developed and emerging economies. Research in Accounting in Emerging Economies, 8, 2-15.

Tsang, E. W. K. (1998). A longitudinal study of corporate social reporting in Singapore: The case of the banking, food and beverages and hotel industries. Accounting, Auditing \& Accountability Journal, 11(5), 624-635.

Uddin, S. N. (2009). Rationalities, domination and accounting control: A case study from a traditional society. Critical Perspectives on Accounting, 20(6), 782-794.

Uddin, S., \& Choudhury, J. (2008). Rationality, traditionalism, and the state of corporate governance mechanisms: Illustrations from a less-developed country. Accounting, Auditing, \& Accountability Journal, 21(7), 1026-1051.

Uddin, S., \& Hopper, T. (2001). A Bangladesh soap opera: Privatisation, accounting, and regimes of control in a less developed country. Accounting, Organizations and Society, $26(7$ and 8), 643-672.

Uddin, S., \& Hopper, T. (2003). Accounting for privatisation in Bangladeshi: Testing the World Bank claims. Critical perspectives on accounting, 14, 739-774.

UNB. (2010). Bangladesh liberation war museum gets Taka 24 crore donation, August, 11, 2010. United News Bangladesh, Dhaka. Retrieved http://bengalnewz.blogspot.com.au/2010/08/bangla desh-liberation-war-museum-gets.html.

Walker, E. T., \& Rea, C. M. (2014). The political mobilisation of firms and industries. Annual Review of Sociology, 40, 281-304.

Weber, M. (1923). GAteS, II (Hinduismus and Buddhismus), pp. 1-398.

Weber, M. (1947). The theory of social and economic organization. New York: Oxford University Press. 
Weber, M. (1968). Basic sociology terms. In G. Roth \& C. Wittich (Eds.), Economy and Society (pp. 3-62). University of California Press.

Weber, M. (1978). Economy and society. Berkeley: University of California Press.

Weber, R. (1990). Basic content analysis (2nd ed., Vol. 49)., Sage University paper series on quantitative applications in the social sciences. Newbury Park, CA: Sage.

Whelan, G. (2012). The political perspective of corporate social responsibility: A critical research agenda. Business Ethics Quarterly, 22(4), 709-737.
Whelan, G., \& Muthuri, J. N. (Forthcoming). Chinese state-owned enterprises and human rights: The importance of national and intra-organizational pressures. Business \& Society.

World Bank. (2005). Economic growth in the 1990s: Learning from a decade of reforms. Washington DC: The World Bank.

www.influenceexplorers.com.

Yadav, V. (2011). Political parties, business groups, and corruption in developing countries. New York: Oxford University Press.

Zaman, I. (2011). Corruption and anti-corruption in Bangladesh. Dhaka: Transparency International Bangladesh. 